NBER WORKING PAPER SERIES

EDUCATING URBAN CHILDREN

Richard J. Murnane

Working Paper 13791

http://www.nber.org/papers/w13791

\author{
NATIONAL BUREAU OF ECONOMIC RESEARCH \\ 1050 Massachusetts Avenue \\ Cambridge, MA 02138 \\ February 2008
}

The views expressed herein are those of the author(s) and do not necessarily reflect the views of the National Bureau of Economic Research.

NBER working papers are circulated for discussion and comment purposes. They have not been peerreviewed or been subject to the review by the NBER Board of Directors that accompanies official NBER publications.

(C) 2008 by Richard J. Murnane. All rights reserved. Short sections of text, not to exceed two paragraphs, may be quoted without explicit permission provided that full credit, including $\odot$ notice, is given to the source. 
Educating Urban Children

Richard J. Murnane

NBER Working Paper No. 13791

February 2008

JEL No. I2

\begin{abstract}
For a variety of reasons described in the paper, improving the performance of urban school districts is more difficult today than it was several decades ago. Yet economic and social changes make performance improvement especially important today. Two quite different bodies of research provide ideas for improving the performance of urban school districts. One group of studies, conducted primarily by scholars of organizational design, examines the effectiveness of particular district management strategies. The second, conducted primarily by economists, focuses on the need to improve incentives. Each body of research offers important insights. Each is somewhat insensitive to the importance of the insights offered by the other literature. A theme of this paper is that insights from both literatures are critical to improving urban school systems.
\end{abstract}

Richard J. Murnane

Graduate School of Education

Harvard University

6 Appian Way - Gutman 469

Cambridge, MA 02138

and NBER

richard_murnane@harvard.edu 
Richard J. Murnane

\section{Educating Urban Children}

\section{Introduction}

America's urban schools are like mirrors, reflecting both the accomplishments and the failures of our society. The accomplishments are evident in graduation ceremonies at urban high schools throughout the country, when students bound for college thank their teachers for the opportunities their parents did not have. The failures are evident in the high drop out rates and low average test scores of students attending urban public schools.

Neither the accomplishments nor the failures of students in urban public schools are recent phenomena. Throughout the last century America’s urban public schools have provided the staircase to a better life for vast numbers of children. The failures are just as long-standing, as described in books written at the end of the $19^{\text {th }}$ century by reformers such as Jacob Riis and Jacob Mayer Rice. ${ }^{1}$

The tendency throughout American history has been to blame the public schools for perceived shortcomings of the nation's young people. Urban schools have been particularly frequent targets. Urban public schools do need to increase their effectiveness markedly, and the primary goal of this chapter is to offer suggestions for improvement. However, the academic performances of urban children will lag behind those of suburban children so long as the nation continues to view the problems facing urban children growing up in poverty as the sole responsibilities of urban public school systems. 


\section{What has not changed}

Ever since free public education became an American institution in the $19^{\text {th }}$ century, urban public schools have served large numbers of children from low income families, many of whom did not speak English at home. Educating poor children is more difficult than educating children from more affluent families, in part, because poor children often come to school hungry and in poor health, and in part, because many of their parents lack the resources and knowledge to reinforce good school-based instruction or to compensate for poor school-based instruction. Equality of Educational Opportunity, the 1966 document by James Coleman and his colleagues, documented in enormous detail the power of the challenge facing schools serving large numbers of poor children. $^{2}$

A related problem is the high mobility rate of children in urban schools - a pattern that Theodore Sizer described in $1968,{ }^{3}$ and that urban school principals today count as one of their greatest challenges. For example, the student mobility rate at Boston's English High School, the nation's oldest public high school, was 32 percent in the 20052006 school year. A continual flow of new students entering classes during the school year requires teachers to devote scarce instructional time to assessing the skills and knowledge of the new entrants and to socializing them to classroom norms of behavior. For this reason it is no surprise to urban teachers that non-mobile students enrolled in classes with high mobility rates make less academic progress during the school year than comparable students enrolled in stable classes. ${ }^{4}$

High student poverty and student mobility rates make working conditions in urban schools difficult. A result is that a great many skilled teachers avoid urban schools 
serving high concentration of poor children. If they do begin their careers in such schools, they transfer out as soon as possible. A consequence is that children who are in especially great need of the nation's best teachers are the least likely to get them. This too is an old pattern, one that the sociologist Howard Becker found in Chicago schools in the early 1950s. ${ }^{5}$

\section{What has changed}

The consequences of a poor education

Until about 30 years ago the primary goals for urban schools were to socialize waves of recent immigrants about the duties of citizenship, to provide all students with quite basic cognitive skills, and to prepare a minority of students for post-secondary education. ${ }^{6}$ Even as late as 1970 these goals made economic sense because the economies of most cities provided large numbers of jobs involving routine manual or routine cognitive work in manufacturing and administrative support occupations. While not exciting, these were jobs that most high school graduates could do. More importantly, they paid enough to allow large numbers of high school graduates and many school dropouts who were willing to follow directions and carry out repetitive tasks to earn a middle class living.

In recent decades changes in the American economy have created pressures on urban schools to reach a new, unprecedented goal - to prepare all students to master a demanding set of academic standards that will prepare them for post-secondary education and training or for jobs with promising futures. ${ }^{7}$ The economic basis for this new demand is illustrated in Figure 9.1, which displays the distribution of U.S. jobs by occupational categories arrayed from lowest paying on the left to highest paying on the right. Between 1969 and 1999, the percentage of the nation’s jobs in manufacturing and 
administrative support occupations - the two occupations that provided work for vast numbers of urban high school graduates - fell from 55 to $39 .^{8}$ In contrast, growth took place in higher paying occupational categories that typically require post-secondary education and in lower paying service sector jobs such as food preparation and janitorial work. A consequence of these changes in the occupational distribution is that high school graduates who leave high school with the skills to succeed in post-secondary education and training find growing opportunities. However, those graduates and dropouts who lack these skills are increasingly relegated to service sector jobs that are growing in number, but that do not pay enough to support children.

Figure 9.1 here

Figure 9.2, which provides an update of the trends in Figure 9.1, shows that the same trends prevail in the most recent data. During the six year period from May 20002006 when the number of jobs in the U.S. economy increased by 7.4 million, the number of jobs in manufacturing and administrative support occupations declined by 3.5 million. While the economic forces underlying these trends are complex, there is every reason to believe that the trends will continue. ${ }^{9}$

Figure 9.2 here

The changes in the U.S. economy have resulted in quite dramatic shifts in the distribution of tasks done by American workers and in the skills needed to do these tasks. This is illustrated in Figure 9.3, which shows how changes in the job mix over the last three decades of the $20^{\text {th }}$ century affected the types of tasks carried out by the American work force. ${ }^{10}$ Especially important are the growing importance of jobs requiring expert thinking and complex communication. We will return to these skills later in the paper in discussing strategies for improving urban high schools. 
Figure 9.3

The economic trends displayed in Figures 9.1, 9.2, and 9.3 play a large role in explaining the trends in the wages of American workers with different educational attainments that are displayed in Figure 9.4. ${ }^{11}$ In 1979, four-year college graduates earned 46 percent more than high school graduates on average. In 2005 the comparable figure is 74 percent. During this same period the average real earnings of high school dropouts fell by 16 percent. ${ }^{12}$ It is these economic trends that have created the demand on urban high schools to prepare all students to master the skills needed for success in post-secondary education and training.

Figure 9.4 here

The best information on the skills of urban students relative to those of students attending suburban schools shows disturbing patterns. In 2003, 50 percent of eighth graders attending schools in large cities scored below Basic on the National Assessment of Educational Progress mathematics test, compared to 29 percent of eighth graders attending suburban schools. The comparable figures for reading scores are 43 percent and 24 percent. ${ }^{13}$

In summary, as a result of changes in the economy, the consequences of leaving school with weak skills are much greater than they were 40 years ago. This is why improving the skills of urban students is the nation's most pressing educational problem.

\section{$\underline{\text { Standards-Based Educational Reforms }}$}

In the last twenty years almost every state has adopted standards-based educational reforms, often called test-based accountability, as its primary strategy for improving public education. To a significant extent, this strategy is a response to state legislators' frustrations with the consequences of court-mandated school finance reform, 
the dominant approach to improving public schools during the previous two decades. Under court-mandated school finance reforms, many states assumed greater responsibility for funding public schools, reducing reliance on local property taxes. These reforms did lead to significant equalization of per-pupil spending across school districts, usually by increasing expenditures in low-spending school districts. In particular, school spending rose markedly in districts serving high percentages of children from poor families and children of color. However, the increased spending was not accompanied either by a marked increase in or equalization of student achievement. ${ }^{14}$ This led legislators to the conclusion that simply providing public schools with more money was not an effective strategy for improving their performance. Instead, increased funding must be accompanied by increased accountability.

While details of accountability systems vary greatly from state to state, all standards-based educational reforms include three components:

- $\quad$ content standards that specify what students should know and be able to do, performance standards that describe how students should demonstrate their knowledge and skills and what levels of performance meet the standards, and assessments that measure the extent to which students meet performance standards;

- $\quad$ incentives for educators to do the hard work required to prepare all students to meet the performance standards and incentives for students to devote the time and energy needed to meet the performance standards, and

- $\quad$ instructional materials and professional development aimed at providing teachers with the knowledge, skills, and resources needed to prepare all students to meet the performance standards. ${ }^{15}$ 
The passage of the No Child Left Behind Act of 2001 (NCLB) marked a significant change in the federal role in public K-12 education in the United States. NCLB requires that states annually test the reading and mathematics skills of all public school students in grades three through eight. It also specifies that all schools are expected to make adequate yearly progress (AYP) toward ensuring that all groups of students, including groups defined by race/ethnicity and poverty, reach proficiency within 12 years (by 2014). School districts and schools that fail to demonstrate adequate yearly progress for all groups of students are subject to corrective actions that can ultimately include staff replacement and school reconstitution. ${ }^{16}$ NCLB and state accountability systems have put the spotlight on urban schools, highlighting the weak reading and math skills of urban students, and their low graduation rate. In particular, they have put great pressure on urban school systems to improve the English Language Arts and mathematics skills of students.

\section{Isolation of Urban Schools}

One troubling change in urban schools is that they serve many fewer middle class children today than they did in the past. In fact, the vast majority of students served by the nation's largest urban school districts are children of color from low income families. Among the many factors contributing to this disturbing trend is the 1974 decision by the

U.S. Supreme Court in the Milliken v. Bradley case. In this decision, the Court ruled that communities neighboring Detroit had no obligation to participate in an inter-district desegregation plan aimed at improving educational opportunities for Detroit’s overwhelmingly low-income minority student population. In effect, the decision meant that the problems facing urban school districts serving concentrations of minority group children were the responsibility of cities, not of broader communities of Americans. The 
flight of middle-class families from urban schools has markedly increased the challenge of improving these schools.

\section{Competition for Teaching Talent}

Forty years ago K-12 teaching was one of the few professional work opportunities available to female college graduates. This was especially the case for female graduates of color. A consequence was that education did not need to compete very intensely for academically talented female college graduates. In the intervening decades, employment opportunities in other professions have improved markedly for women and minorities. As a result, competition for talent is much more intense than in the past. The public schools are not faring well in this competition, as indicated by the 50 percent decline over the last 35 years in the percentage of the nation's most academically strong college graduates who enter teaching. ${ }^{17}$ The problem is especially acute for urban school districts, where the teaching challenges are especially difficult and the working conditions are often especially poor.

\section{Teachers' Unions}

Forty years ago, very few urban school districts engaged in collective bargaining with teacher unions. Today teacher unions are important players in most urban school districts. Many urban teachers' contracts specify not only salary scales and fringe benefits. They also specify many things once considered management decisions, such as maximum class size, length of the school day and school year, number of teaching preparations, amount of time devoted to training (typically called professional development), and procedures for filling teaching vacancies.

There is no question that changes are needed in the contracts under which teachers in many urban school districts work. Particularly troubling are seniority rules 
governing transfers that contribute to high teacher turnover rates in schools serving concentrations of poor children. At the same time I believe it is a mistake to view teacher unions as powerful villains opposing needed reforms. Urban teacher unions became powerful because many urban teachers felt besieged by the conditions under which they worked and wanted a voice in improving these conditions. Tenure and seniority rights to transfers are not new. They became part of contracts long before urban public schools were charged with preparing all students to meet demanding academic standards. They were among the modest perquisites that came with relatively low paying, difficult jobs with few opportunities for advancement.

Today urban school districts face unprecedented challenges and need employment contracts that are very different from those negotiated in the past. In particular, contracts are needed that enable school districts to attract and retain academically talented teachers in all subject fields, that induce them to work in the schools where they are most needed, that create incentives and opportunities for teachers to work together to improve instruction, and that define strategies for identifying ineffective teachers, supporting their improvement, and dismissing those who remain inadequate. Unfortunately, it is not obvious just what contract provisions will contribute to these objectives. Mistakes, especially if not corrected in a timely fashion, are costly because the teachers urban districts most want to attract and retain have compelling alternative employment opportunities. Unions can play a critical role in enabling urban school districts to move toward human resource policies aligned with standards based educational goals. They can do this by articulating the concerns of effective teachers, by collaborating on the design of teacher evaluation procedures, and by providing timely feedback about potential reactions to proposed changes in contracts and human resource policies. ${ }^{18}$ 
Peer Assistance and Review (PAR) programs provide one example of promising collaborations. Districts including Toledo, Cincinnati, and Montgomery County have negotiated PAR programs, under which teacher unions and school district management work together in evaluating teachers, in providing assistance to those whose performance is sub-par, and in dismissing those teachers whose performance does not improve remarkably after receiving assistance. Bonnie Cullison, the President of the Montgomery County Teachers Union, provided the following summary of her district's program:

For the 10 years prior to PAR being instituted in Montgomery County, exactly one person had left the system because of performance. ... In the six years since PAR has come in, 400 people have left the system because of performance. Now many of them decide to leave without going through the dismissal process. ${ }^{19}$ Of course, using the collective bargaining process to reach agreements that result in improved education for children requires great skill on the part of both union and school district leaders. Often these skills have been lacking.

In summary, improving urban education is both more important now than in the past and more difficult. It is more important because the economic consequences of leaving school without strong skills are greater than in the past. The work is more difficult because urban schools lack the human resources provided by middle class students and their parents and because they must compete for teaching and leadership talent to a much greater extent than they did in the past.

Two quite different bodies of research provide ideas for improving the performance of urban school districts. One group of studies, conducted primarily by scholars of organizational design, examines the effectiveness of particular district management strategies. The second, conducted primarily by economists, focuses on the 
need to improve incentives. Each body of research offers important insights. Each is somewhat insensitive to the importance of the insights offered by the other literature. A theme of this chapter is that insights from both literatures are critical to improving urban schools.

\section{District Improvement Strategies}

Improving urban elementary schools

A consensus is emerging on the components of urban school district reform strategies that are successful in improving elementary schools. Elements include systemwide, demanding curricula that are well aligned with state standards and assessments, a new partnership between the central office and city schools known as reciprocal accountability, the use of student assessment results to guide decision-making, and a consistent strategy to support English-language learners. Since each of these elements is either relatively new or controversial, I provide an explanation of each.

There are two advantages to adopting common curricula for all elementary schools. First, it facilitates the integration into classes of the many students who move during the school year from one district elementary school to another. Second, it reduces the cost of providing professional development aimed at increasing teachers' skill in teaching core curricula. Alignment of curricula with state standards is essential so that teachers have reason to believe that helping their students to master the curriculum will result in good scores on mandatory state tests. The reason to adopt relatively demanding curricula is to assure the district's best teachers that they have the tools to prepare students to succeed in subsequent education. However, since curricula that challenge students to master higher order skills are difficult to teach effectively, a corollary is the 
importance of providing the ongoing training needed to learn to teach the curricula well. This is where the new role for the central office comes in. ${ }^{20}$

Reciprocal accountability is a term characterizing the relationship between the central office and individual schools. ${ }^{21}$ On the one hand, the district leadership requires that schools make progress in improving student achievement. If they do not, there are consequences, often beginning with a change in leadership. On the other hand, the district leadership commits itself to providing the resources that schools need to accomplish this goal. These include well educated teachers, on-going training that increases principals' and teachers' effectiveness, enough time in the school day for teachers to both work together at instructional improvement and to provide extra help to lagging students, and the resources needed to support the learning of students with varying needs.

Making reciprocal accountability a reality requires a new role for the central office. It must recognize that schools vary in capacity and need to be treated differently. Low performing schools need special attention and support. Schools making real progress need the freedom to use resources in new ways. To provide the resources schools need, the district leadership must reallocate resources away from the many programs and activities that absorb funds but do not contribute in a coherent fashion to improving students' literacy and mathematics skills in the district as a whole.

Given the importance of preparing all students to master state learning standards, it is important to track progress toward this goal and to use data to inform decisionmaking. One use of data is to assess whether professional development is making a difference. Another is to identify schools in need of intervention. Yet a third is to provide school faculties with up-to-date, fine-grained information on the extent to which 
individual students are mastering critical skills. (Formative assessment is the term used to describe such information.) School faculties need to learn how to use the results of formative assessments to assess the effectiveness of their instruction, to identify skills that need to be taught again or taught differently, and to figure out ways to improve instruction and to provide lagging students with extra learning time. Central office leadership is needed in developing or purchasing the assessments, in providing school faculties with the results in an easy-to-understand format, and in providing the training school faculties need to learn to make constructive use of the assessment results. ${ }^{22}$

A critical challenge in most urban school districts is educating students who come to school with little or no proficiency in English. For example, in 2007, 18 percent of Boston's 57,000 public school students were English-language learners. They came from 40 different countries. The largest native language groups were Spanish, Haitian Creole, and Chinese, but there also were students speaking dozens of other languages. State and federal accountability systems requiring that the scores of English-language learners on state examinations be included in calculations of schools' performance ratings have increased pressure on schools to develop the English proficiency of English-language learners.

How best to teach English-language learners has been the subject of great controversy in the United States. ${ }^{23}$ On the one side are advocates of bilingual education, an approach that combines some native-language instruction with instruction in English. They argue that developing students' reading abilities in their native language will help them to learn to read in English. On the other side are advocates of English-only instruction, who argue that instruction in a student's native language slows progress in mastering English. In practice, the choice of instructional method is much less clear-cut 
than a dichotomous choice between bilingual education or English-only instruction. For example, some bilingual programs begin with instruction solely in students' native language and then make a transition to English. Others employ two teachers with each group of students from the outset, one of whom teaches in the student's native language for part of the day and the other teacher teaches in English for part of the day. Some programs aim to move children to English-only instruction within a year, while others continue with instruction in two languages for several years.

There are also many variants of English-only approaches. At one extreme, students are placed in regular classes with native-English speakers and expected to “catch-up.” In another approach, called structured English immersion, students are grouped together for a specific period of time and taught content in English using special techniques accessible to English-language learners.

Of course, the quality of implementation of any particular approach, whether it be a form of bilingual education or English-only instruction, varies from classroom to classroom, depending on the skills of the teachers, the time allotted to learning to read, the availability of resource materials, and the backgrounds and skills of the students. However, such subtleties are typically lost in the heat of debates about bilingual education. The intensity of the controversy is illustrated by the passage of laws in several states, including California and Arizona, prohibiting or severely restricting the use of bilingual education in public schools.

While many evaluations of the relative effectiveness of bilingual education and English-only instruction have been conducted, only a small percentage of studies have sufficiently rigorous designs to provide compelling evidence. A recent meta-analysis of evaluations with satisfactory designs reached two important conclusions. The first is that 
bilingual instruction does not hamper academic progress in either a student's native language or in English. Indeed, bilingual education has a small advantage, on average, over the English-only approach. The second is that program quality matters more than the choice of a bilingual education or an English-only approach. In other words, what is most important is having instructors skilled in teaching English-language learners, curriculum that is accessible to and engages English-language learners, sufficient time devoted to acquiring literacy skills, close monitoring of the progress of each child, and rapid intervention when a child is lagging. All of this is just one more aspect of reciprocal accountability between the central office and individual schools.

The four elements that are part of successful school district improvement strategies make sense. Indeed, to some readers, they may seem obvious. However, implementing them requires a significant reorganization of central offices, which historically have been large bureaucracies divided into departments (often derogatively labeled "silos"), each of which functioned with its own standard-operating procedures and did not coordinate its work with that of other departments. The typical district had hundreds of programs with different objectives and funding sources. The central office's role was to administer the funding of these programs, not to ask whether they contributed to a coherent instructional program. Most districts kept track of students' scores on endof-the-year achievement tests and some eventually sent these scores to schools. However, until quite recently, most central offices did not think in terms of an obligation to put in place a system of formative assessments that would provide school faculties with timely, fine-grained information on students' skills. In most urban districts there was one office responsible for the education of English-language learners, with little 
coordination between the work of that office and the operations of other central office departments.

\section{Improving Urban Secondary Schools}

Among the most troubling indicators of the problems of urban education are the extraordinarily high dropout rates of students from urban high schools and the large number of urban high school graduates who enroll in two-and four-year colleges but fail to pass the exams required for entry into credit-bearing courses. Fifteen years ago, when states began standards-based education reforms, many analysts thought that these problems would go away in time. The logic was that the poor reading and math skills of a great many ninth graders stemmed from low quality elementary school education. Thus, improving elementary schools would solve crippling problems that besiege secondary schools. This logic has turned out to be faulty. Many urban school districts have markedly improved the reading and math scores of elementary school students. Yet the dropout rates of students from their urban high schools do not seem to have declined. Nor have the scores on state tests administered to urban $10^{\text {th }}$ graders improved nearly as much as the scores of elementary school students. This pattern has led to the realization that improving secondary schools, including both middle schools and high schools, is the biggest challenge facing urban school districts.

Recent research has shed light on the elements of effective strategies to improve urban secondary schools. Critical dimensions include:

- creating a personalized and orderly learning environment in which students and teachers treat each other respectfully,

- identifying students who enter middle schools and high schools with poor academic skills and intervening intensively to improve these skills, 
- improving the quality of instruction and making a stronger case to students that particular skills and knowledge are important to acquire,

- connecting students to the world of work,

- strengthening connections between high schools and community colleges. $^{24}$

The most visible evidence of this strategy is the creation of many small high schools - often by dividing large comprehensive high schools into three or four smaller schools housed in the same building. Other common actions are the creation of doublelength instructional periods in English and mathematics for ninth graders with weak skills. In many districts these sensible changes have taken place quite rapidly, to a large extent because they could be done by administrative fiat, if sufficient resources are available. It has proven more difficult, however, to improve instruction and engage students.

\section{Why is progress so slow?}

If urban districts such as Boston and San Diego have made progress by embracing the district improvement strategy described above, why have not all urban districts done so? Why has the rate of progress been so modest in even the most rapidly improving urban districts? There are several contributing explanations. First, attempts to implement the district-wide improvement strategies described above encounter significant political resistance. Some comes from central office staff that lose their jobs as resources are reallocated from peripheral programs to school-based professional development aimed at improving English and mathematics instruction. Some comes from central office staff told that reciprocal accountability means they must serve schools rather than require that schools follow their rules. Some comes from teachers who are told that they must work 
with colleagues and coaches to improve instruction and make it more consistent instead of closing the classroom door. Some comes from parents angry that principals whom they personally like are replaced due to stagnant test scores. Sustaining commitment to a coherent district improvement strategy in the face of such resistance requires significant support from the school board and the business community. Often such support dwindles as resistance to change becomes evident. ${ }^{25}$ The brief tenure of urban superintendents (less than three years, on average) also contributes to resistance. Why should central office staff, teachers, and parents embrace significant system-wide changes if the initiator of the changes is unlikely to see them through? Of course, the causation works the other way as well: resistance leads many superintendents to resign rather than to fight for change.

A related reason why only a relatively small minority of urban districts has successfully embraced a coherent system-wide instructional improvement strategy is that there is no recipe for doing so. Instead, each superintendent must find his or her own way of building and sustaining support for change and for overcoming the many sources of resistance. This is vividly illustrated by the different approaches taken by Alan Bursin and Thomas Payzant, both of whom led districts that significantly improved student achievement under their leadership. ${ }^{26}$

A third reason is that the incentives in place for many actors in urban education do not support an unwavering commitment to improving student achievement. These incentives are a legacy of a time when students needed fewer skills to earn a decent living and an industrial mode of production was a serviceable way to organizing schooling. These incentives hinder progress today.

\section{Improving Incentives}


In analyzing the problems with American public schools and urban public schools in particular, economists have emphasized that the system provides the wrong incentives for teachers, for school administrators, and for students. In this section, we explain these arguments.

Incentives for teachers

Virtually all public school districts in the United States use compensation systems for teachers that reward advanced degrees and years of teaching experience and nothing else. School districts typically adopted these uniform salary scales in the middle of the $20^{\text {th }}$ century as part of efforts to professionalize teaching. Often they replaced arrangements in which the compensation of individual teachers depended on their gender and on their relationships with school board members.

While the uniform salary schedule may have made sense in the past, it creates a variety of problems today for urban school districts striving to use scarce resources wisely. One problem is the difficulty of attracting skilled teachers in fields such as chemistry and computer science that provide strong private sector employment opportunities and in fields such as special education where the work with children may be especially draining. A second is that the pay scale creates incentives for teachers to acquire Master’s Degrees even though most studies indicate that teachers with Masters Degrees are not more effective than those without them. A third is the lack of incentives for teachers to invest in developing skills that do enhance their effectiveness. A fourth is the lack of incentive for skilled teachers to work in the schools serving high concentrations of low-achieving students. Indeed, teachers use the seniority rights that are part of most collectively bargained contracts to move away from such schools. ${ }^{27}$ 
Among the most common initiatives aimed at improving incentives for teachers are pay premiums for teaching in schools serving high percentages of poor children. Often the pay premiums are coupled with increases in the length of the school day and school year and with training aimed at improving instructional quality. To date the evidence on the consequences of these initiatives is extremely limited. However, one study based on data from North Carolina suggests that initiatives of this kind have promise. This study found that a $\$ 1,800$-per-year retention bonus for math, science, and special education teachers working in high-poverty or academically failing secondary schools reduced eligible teachers' turnover rates by $12 \% .{ }^{28}$ Unfortunately the study did not address the critical question of whether the reduction in teacher turnover resulted in increases in student achievement.

Another type of initiative ties teachers' pay to demonstration of mastery of particular knowledge bases and skills. One well known initiative of this type is National Board Professional Teacher Certification, a voluntary program under which teachers with at least three years of experience who successfully demonstrate a range of skills over a year-long evaluation process are designated as Board Certified Teachers. A number of states and school districts offer significant pay premiums to teachers who have acquired this status. A recent study showed that elementary school teachers who achieved Board Certification were more effective in increasing students' reading and math test scores than were teachers who applied for Board Certification but did not succeed in obtaining it. $^{29}$ These results suggest the value of using aspects of the board certification process in making teacher licensing and tenure decisions.

Yet another type of initiative provides pay premiums to teachers or to the entire faculties of schools that are effective in improving students' scores on standardized tests. 
The direct link between student performance gains and teachers' pay makes this type of policy attractive to many policymakers. It troubles many teacher union leaders, however. One reason is that test scores are imperfect indicators of the skills students should master. A second is that test scores depend not only on teachers' efforts and skills, but also on many factors beyond teachers' control. It is clear that the consequences of performancebased pay plans (sometimes called "new-style merit pay") will depend critically on the quality of the student assessments and the development of "value-added" models that provide credible estimates of teachers' contributions to test score gains. ${ }^{30}$ While there is little evidence on the consequences of teacher compensation plans that link pay to student test scores, a recent evaluation of a short-lived program in Israel found a positive impact on student achievement. ${ }^{31}$

Perhaps the most interesting teacher compensation plan adopted by an urban school district is Denver's ProComp plan. This plan includes a combination of the type of incentives described above: extra pay for teaching hard-to staff subjects or teaching in hard-to-staff schools, extra pay for demonstrated mastery of knowledge and skills, and extra pay for students' growth in test scores. To date, there is no solid evidence on the extent to which the plan increased the district's ability to attract and retain skilled teachers and to increase students' achievement. However, the plan does demonstrate that it is possible for school district management and teacher union leaders to bring about significant changes in teachers' contracts through collective bargaining.

\section{Incentives for school leaders}

School principals play key roles in determining the effectiveness of the schools that they lead. Typically they hire teachers, specify their teaching assignments, and evaluate their performances. In many school districts principals also specify the 
professional development activities teachers engage in. Principals also typically assign students to classes and decide which students will be retained in grade. The value of skilled principals is frequently illustrated by profiles that appear in the media of schools with strong leaders that have been uncommonly successful in educating disadvantaged students.

Despite the central role of school principals in leading schools, many urban school districts do not provide incentives to attract and retain effective school leaders. The problems are of three kinds. First, in many urban districts school principals do not have control over many resources. Consequently they lack the tools to lead schools effectively. Second, the job has become much more difficult, with pressure to improve the test scores of all students. Many districts lack effective training for developing the skills principals need to achieve these relatively new goals. Third, in many districts, effective principals are paid on the same scale as ineffective principals. Moreover, some state labor laws make it very difficult for school district superintendents to remove ineffective principals. The net result is that many urban public schools lack effective leaders.

In recent years some states have passed legislation that makes it easier for school district superintendents to remove school principals who are not effective. Some states and urban districts have also introduced performance-based contracts for school leaders. These types of initiatives make sense as part of strategies to improve school leadership. However, whether particular initiatives succeed in attracting talented educators to leadership positions and ultimately in improving student achievement is an empirical question. Currently, there is very little evidence about the design of incentives that contribute to these goals. 


\section{$\underline{\text { Incentives for students }}$}

Mastering difficult skills takes hard work. Students who aspire to attend highly competitive colleges know this and do the requisite work. However, historically the majority of urban high school students have seen little reason to do the hard work that skill mastery takes. They could obtain enough credits to graduate from high school by doing minimal work in undemanding courses. They correctly perceive that differences in math and reading skills are not rewarded when they apply for entry-level jobs as 18-yearolds. There is always some college that will accept them if they have a diploma. ${ }^{32}$

A number of initiatives are underway to improve incentives for students. More than 20 states currently require high school students to pass state-mandated English and mathematics examinations in order to obtain a high school diploma. The intent of these test-based graduation requirements is to create incentives for students to focus greater attention on academic work and to create a signal to employers that high school graduates do possess basic cognitive skills. However, passing these exams does not mean that students are ready for college or the demands of jobs with promising futures. While more than 70 percent of high school graduates enter two-and four-year colleges, more than one quarter must take remedial English and mathematics courses before registering for courses that provide college credit, and the percentage is much higher for urban students. More than 60 percent of employers rate high school graduates' skills in writing and basic math as only "fair" or "poor." 33

A new initiative undertaken by a growing number of states, working together under the auspices of the American Diploma Project, seeks to align high school standards, assessments, and graduation requirements with the knowledge and skills needed for success in post-secondary education and in jobs with growth potential. The 
hope is that this will provide educators and students with clear signals about the adequacy of the work they do together in high schools.

It makes sense for states to align high school standards, assessments, and graduation requirements with the knowledge and skills needed for post-secondary education and work. Public higher educational institutions could create incentives for high school students to master the more demanding skills required for high school graduation by committing to use students' scores on recalibrated state exams for college course placement. In other words, knowledge that scoring well on high school exit exams would guarantee acceptance into college courses that count toward degree attainment (as opposed to being funneled into "developmental courses" that do not) would increase students' incentives to do the hard work needed to attain mastery of important skills. ${ }^{34}$

There is another benefit of encouraging states to align high school graduation requirements with the skills needed to do college level work. This would almost inevitably lead states to modify content standards at the earlier grades so that students would be prepared to do more demanding high school work. The net result is likely to be a reduction in the variation across states in standards and assessments. Moving toward a common set of national standards and assessments makes sense in a country with a mobile population and an increasingly integrated economy.

One caution is the need for care in determining just what skills are important for success after high school graduation. The tendency is to ratchet up standards in areas in which it is relatively easy to measure skills, such as mathematics, and to neglect skills that are critical to success in a variety of post-secondary educational and work settings, but that are difficult to measure. These include oral communication skills, teamwork skills, and job search and interviewing skills. ${ }^{35}$ 
A ten-year experimental study of career academies illustrates that reading and math skills are not the only skills important to success after high school. Career academies are schools within schools that embrace three design principles. First, they are generally smaller learning communities, and are comprised of a group of students embedded within a larger high school, who take classes together for at least three years, and who are taught by a team of teachers drawn from different disciplines. Second, they offer a college preparatory curriculum with a career theme, which enables students to identify relationships among academic subjects, and understand how they are applied in a broad field of work. Third, they generally include partnerships with local employers who provide work-based learning opportunities for students enrolled in the Academies.

In 1993, one of the nation's leading contract research firms, MDRC, undertook an experimental study of the educational impact of Career Academies. Nine career academies, for which there was excess student demand, participated. All of these academies were located in urban school districts and served large percentages of students living in poverty. Lotteries were used to determine which interested students were offered places in the career academies. Both the students who were offered places (the treatment group) and those who lost out in the lottery and enrolled in other school programs (the control group) were followed through high school and for four years after graduation. A variety of indicators of success (reading and math scores, course grades, on-time graduation, college enrollment and completion, labor market earnings) were measured for all participants.

The results of the career academy evaluation are quite striking. Both treatment and control group members had academic skills, high school graduation rates, and college enrollment rates that were higher, on average, than the national average for students with 
similar demographic characteristics. (This reflects the greater than average motivation of students who wanted to enroll in career academies.) However, students who were offered places in the career academies did not fare better on these measures of academic success than the students in the control group. Fortunately, MDRC researchers continued to follow students from the treatment and control groups into the labor market. They found that males who had been offered places in a career academy earned \$10,000 (18\%) more than males in the control group in the four year follow-up period after high school. The labor market benefits were especially large for males who were at risk of dropping out of high school at the beginning of the experiment. The likely explanation for this pattern is that enrollment in career academies and the associated opportunities for work place internships and jobs enabled students to acquire skills that were important to labor market success even though they were not captured by scores on standardized reading and math tests. ${ }^{36}$

A critical lesson from the MDRC study is the importance of supporting the development and implementation of programs like career academies that offer rich opportunities for urban students to acquire the communication and teamwork needed in middle class workplaces. One way to do this might be to make demonstration of these skills a condition for high school graduation. Of course, doing this would require different and more expensive types of skill assessments than the standardized examinations states currently use to measure mathematics and English skills. Experimenting with such alternative assessments is important in that it might stimulate the development of high school programs that provide urban students with critical skills not captured by scores on standardized reading and mathematics tests.

Incentives and capacity building are complements 
As described above, states and urban school districts have recently introduced a wide variety of policies aimed at improving the alignment between incentives and the goal of dramatically improving students' skills. This concern with incentives is a step forward for public education. However, it is important to keep in mind that it is much more difficult to get incentives right than it is to point out the flaws in current incentives. Many initiatives that have seemed promising in the past, such as basing teachers' pay on supervisors’ evaluations (sometimes called “old-style merit pay”), have not improved the performance of urban school districts. ${ }^{37}$ Moreover, some incentives have elicited dysfunctional responses. Documented examples include changing students' answers on high stakes tests ${ }^{38}$ and suspending students likely to score poorly on such tests. ${ }^{39}$

Stating the incentive challenge in a positive way, people like to do what they do well. $^{40}$ Consequently, a critical complement to appropriate incentives is a management system that provides teachers and administrators with the skills to improve student achievement and students with the consistently high quality instruction they need to master important skills.

\section{Catalyzing and Monitoring Progress}

As described above, research on the reform efforts of states and urban school districts over the last 20 years provides guidelines about the elements of successful school improvement strategies and promising changes in incentives. These are steps forward. However, guidelines are not recipes. Every district will need to work out the details of its strategy for systemic change and improved incentives.

Given the power of inertia, it is important to catalyze change. Given the potential for mistakes in designing and implementing systemic improvements and new incentives, it is important to monitor whether changes are resulting in better education. Two types of 
information can be important in catalyzing change and monitoring progress. The first comes from the choices parents make about where to send their children to school. The second comes from systematic evaluations of student outcomes. We consider each in turn.

\section{$\underline{\text { A role for school choice }}$}

One source of information about the effectiveness of incentives and school management initiatives are parents' choices about where to send their children to school. Parents with significant financial resources who are unhappy with their child's public school can either move to a school district with better public schools or send their child to a private school. Historically low income parents have typically lacked these options.

In an attempt to provide parents with choices, many urban school districts have established public school choice programs. While details vary greatly among districts, choice plans typically allow parents to rank their school preferences and then a system that gives priority to neighborhood students and to siblings (and sometimes to racial balance) is used to determine assignments to oversubscribed schools. The 2001 Now Child Left Behind law takes school choice a step further by mandating that school districts provide school choices for children currently attending schools that have not made Adequate Yearly Progress for two years in a row.

Most public school choice plans suffer from two related problems. First, the supply of effective schools does not grow over time. Consequently, many parents do not get their first choices and remain frustrated with their children’s schooling options. Second, schools that are not popular among parents are typically filled with students who lose out in the lottery. Consequently, there are no strong signals to the educators staffing these schools that the schools need to change or to close. 
In recent years 40 states have passed legislation that supports the creation of charter schools, which are publicly funded schools that typically establish their own curricula and do not operate under many of the rules that constrain conventional public schools. Currently there are almost four thousand charter schools in the United States serving approximately one million students.

Supporters of charter schools envision two types of benefits. The first is that they provide new schooling options for parents who are dissatisfied with conventional public schools and lack the resources to use private schools. Second, by competing with conventional public schools for money and students, they will catalyze improvement in public schools. One plausible improvement mechanism is that the potential loss of students to private schools will nudge urban school districts and teacher unions toward contract revisions that provide better alignment of incentives with school district improvement goals.

A related initiative is the call to have public funding for education follow students. In other words, a particular funding level would be attached to each student, with the level higher for students with documented special learning needs. Every public school, whether a conventional public school or a charter school, would operate on the revenues from the students it attracted. If a student changed schools, the funding would move with the student. The aim of this proposal is to create strong incentives for school districts and individual schools to create educational programs that appeal to parents and students.

In principle, both charter schools and funding that follows students make sense as components of a strategy to improve urban education. However, whether they fulfill their promise depends critically on the details of the laws and rules governing their 
operation. To cite just one example, currently urban charter schools are less likely to serve students with special needs than are conventional urban public schools. Whether this puts conventional urban districts at a disadvantage in competing for students depends critically on whether funding formulas accurately reflect the extra costs of educating children with special needs.

Currently charter schools laws and school funding formulas vary enormously across states. It is much easier to start a charter school in some states than in others. In some states charter schools are significantly disadvantaged relative to conventional public schools in access to funding and physical facilities. In other states the playing field is

more equal. In yet other states, legislation and rules make it difficult for public schools to compete with charter schools. Much needs to be learned about the tensions between designs of charter school laws and funding formulas that encourage the creation of educational alternatives and designs that create a level playing field on which schools can compete for students and funding.

\section{Monitoring progress}

Advances in computer-based administrative record keeping and data retrieval make it increasingly possible to monitor a variety of student outcomes. For example, most urban districts currently have, or could develop, the data-analytic capacity to monitor progress in attracting and retaining a skilled teaching force. Critical data to track would be the percentage of new teachers hired before the start of the school year, the number of teachers who apply for openings in schools targeted for improvement, and these schools' success in attracting and retaining their first choices.

A second important type of information consists of longitudinal data on students' mathematics and reading skills. Such data can support the tracking of students' 
achievement growth over time, something that can be especially important in judging the performance of schools serving extremely mobile student populations. For example, some of these schools have low average test scores, but have achieved significant success in increasing the achievement of students who had spent the entire year at the school. Identifying such schools is critical to making informed judgments about which schools are doing a good job under difficult circumstances and which schools are in need of significant intervention.

Another area in which better data are available than in the past concerns outcomes for high school students. For example, a growing number of states have state-wide student tracking systems that provide more accurate information on student dropout rates than was available in the past. It is also possible now at relatively low cost to track the college progress of high school graduates of particular schools or districts through a service called StudentTracker, provided by the National Student Clearinghouse. As stated on its website, this service provides answers to the following questions:

Where did my program's former participants enroll in college?

How long did their educational efforts persist?

Did they transfer between colleges?

Did they receive a college degree? If so, which degree?

Where did they graduate from college?

What was their college major? ${ }^{41}$

Tracking this information over time would provide important evidence of the progress urban high schools are making in preparing students to thrive after graduation.

\section{A National Problem Requiring a National Solution}


Putting in place the type of system-wide school improvement plan and incentives described in this chapter will improve urban schools. However, urban school districts cannot do these things on their own. Progress will also depend critically on state and federal policies.

State collective bargaining laws play an important role in either facilitating or hindering changes in incentives for teachers and school administrators. State school finance policies influence whether urban districts have the resources to serve intensely disadvantaged student populations. State educational accountability systems influence the incentives for skilled teachers to work in urban school systems and the consequences when schools are judged to be failing or succeeding.

Federal government policies also influence urban school districts in important ways. For example, the 2001 No Child Left Behind Act creates strong pressures on urban districts to improve the reading and math scores of all groups of students defined by race/ethnicity, and poverty and special education status. While this is a strength, the law also has significant weaknesses that affect urban school districts. For example, by placing schools and districts in only one of two categories (making Adequate Yearly Progress or failing to), the law does not distinguish between schools in drastic need of intervention, and those that are making progress with most groups of students. Another respect in which federal government education policies matter is in supporting research. The federal government provides a significant portion of the funding for research on the consequences of systemic reform strategies and new incentives for educators and students. This research is critical to increasing the knowledge base available to policymakers charged with improving urban schools. 
In closing, I return to the image of urban schools as mirrors. The accomplishments and failures of children growing up in large cities reveal a great deal about the nation's success in providing high quality education to urban students. However, they also reflect the nation's success in providing employment, health care, and public safety to city dwellers. Finally, they provide us with an image of the future of America's cities. For all these reasons improving the lives of urban children is a pressing national priority. 
Figure 9.1

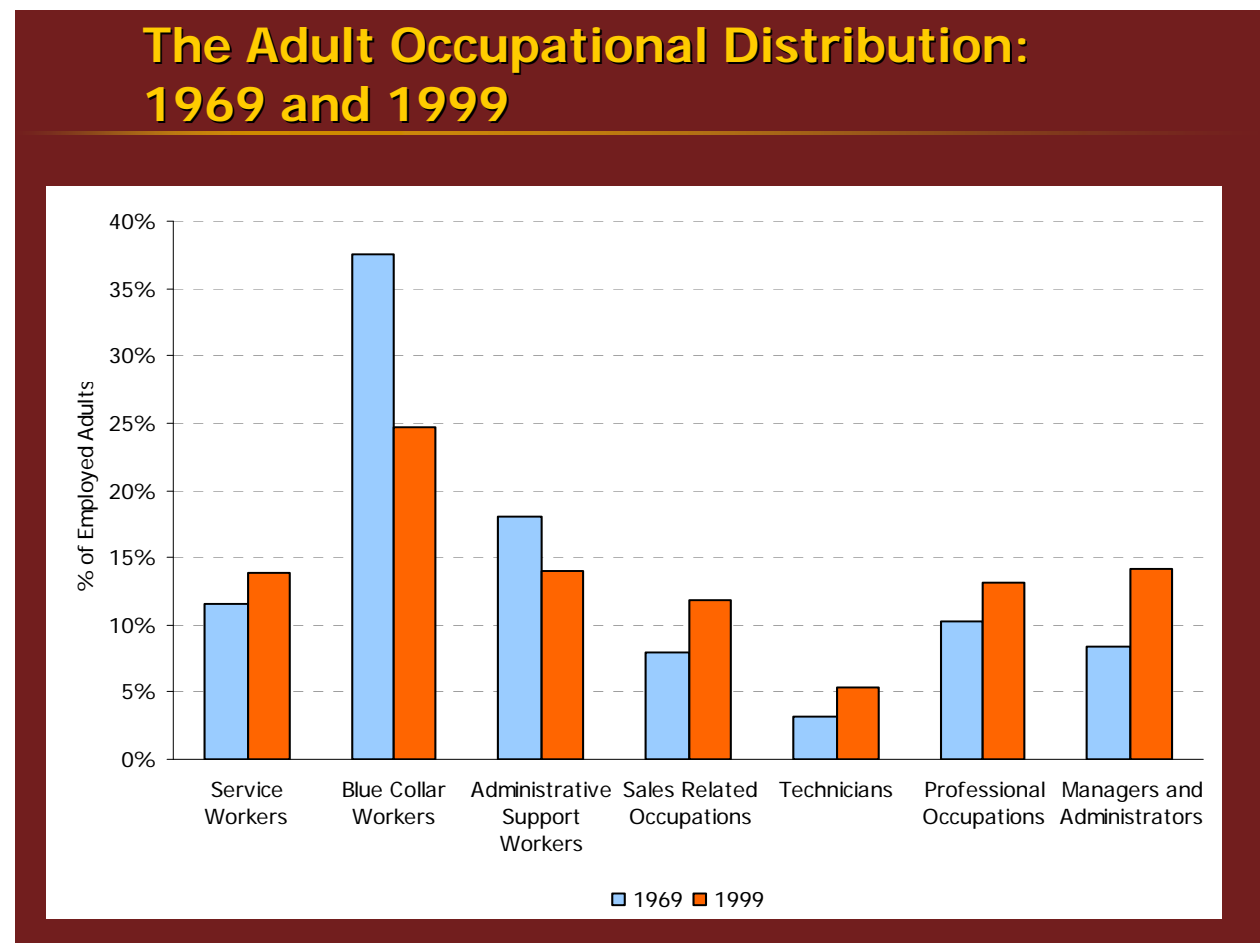


Figure 9.2

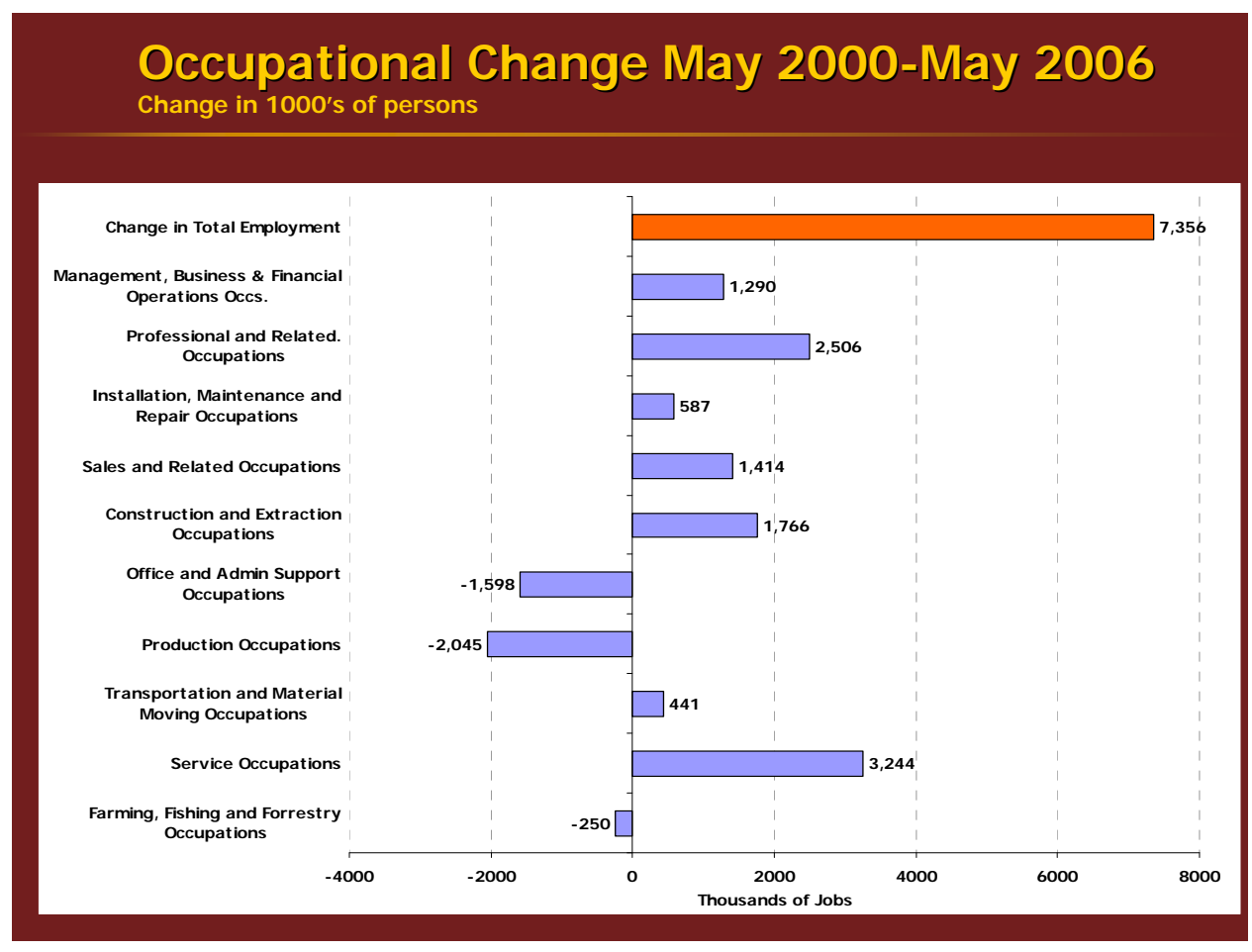


Figure 9.3

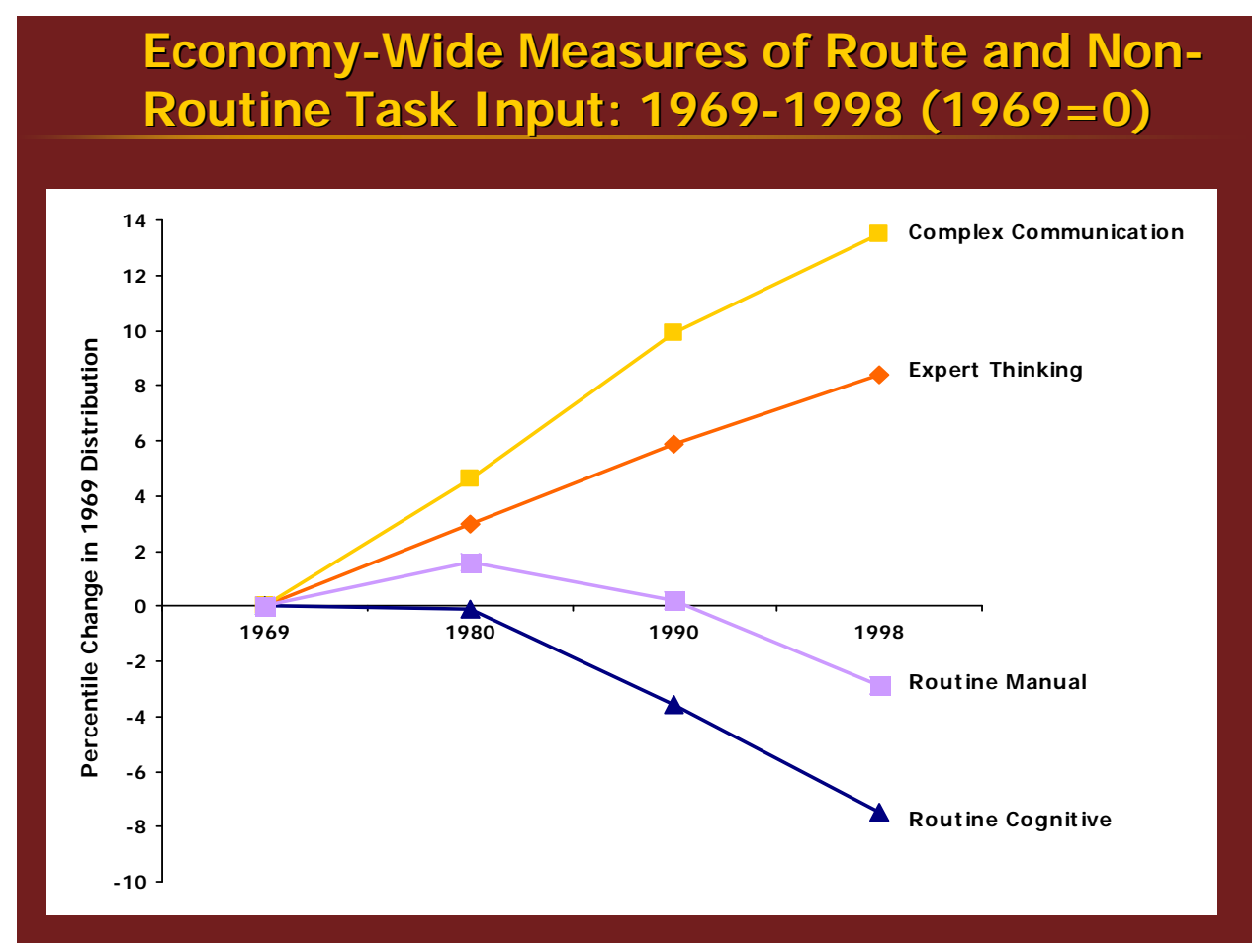


Figure 9.4

Real hourly wage by highest educational attainment for U.S. workers: 1973-2005 (2005 dollars)

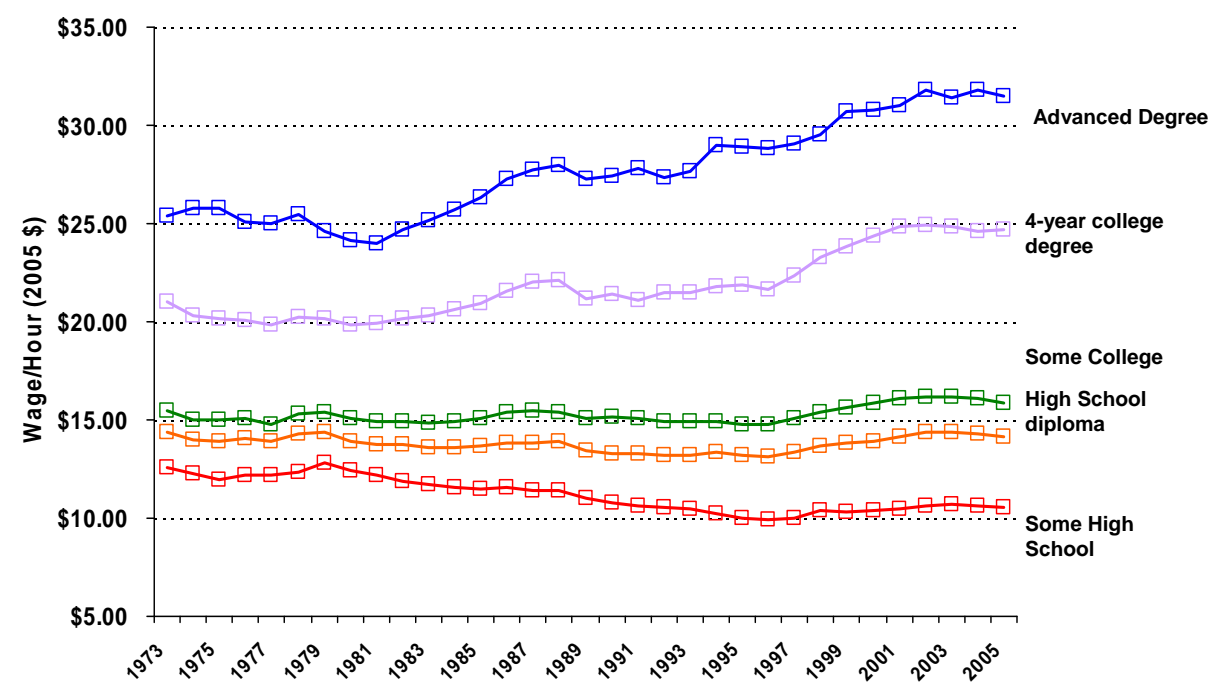


References

Autor, D. H., F. Levy, et al. (2003a). "The Skill Content of Recent Technological Change: An Empirical Exploration." Quarterly Journal of Economics 118(4): 1279-1333.

Becker, H. S. (1952). "The Career of the Chicago Public SchoolTeacher." American Journal of Sociology 57(5): 470-77.

Bishop, J. H., F. Mane, et al. (2001). The Role of End-of-Course Exams and Minimal Competency Exams in Standards-Based Reforms. Brookings Papers in Education Policy 2001. D. Ravitch. Washington, D.C., Brookings.

Cantrell, S., J. Fullerton, et al. (2007). National Board Certification and Teacher Effectiveness: Evidence from a Random Assignment Experiment. National Bureau of Economic Research Economics of Education Workshop. Cambridge.

Clotfelter, C., E. Glennie, et al. (2006). "Would Higher Salaries Keep Teachers in HighPoverty Schools? Evidence from a Policy Intervention in North Carolina." National Bureau of Economic Research Working Paper No. 12285.

Coleman, J. S. and a. others (1966). Equality of Educational Opportunity. Washington, D.C., Office of Education, U.S. Department of Health, Education, and Welfare.

Corcoran, S. P., W. N. Evans, et al. (2004). "Women, the Labor Market, and the Declining Relative Quality of Teachers." Journal of Policy Analysis and Management 23(3): 449-470.

Elmore, R. F. (2002). Bridging the gap between standards and achievement: The imperative for professional development in education. Washington, DC, Albert Shanker Institute: 40. 
Evans, W. N., S. E. Murray, et al. (1999). The Impact of Court-Mandated School Finance Reform

Equity and Adequacy in Education Finance: Collected Papers H. F. Ladd. Washington, D.C., National Academy Press.

Figlio, D. N. (2005). "Testing, Crime and Punishment." National Bureau of Economic Research Working Paper No. 11194.

Francis, D. J., N. K. Lesaux, et al. (2006). Language of instruction for language minority learners. Developing Literacy in a second language: Report of the National Literacy Panel. D. L. August and T. Shanahan. Mahwah, N.J., Erlbaum Associates: $365-414$.

Freeman, R. B. (1985). What Do Unions Do. New York, Basic Books.

Graham, P. A. (2006). Schooling America: How the Public Schools Meet the Nation's Changing Needs New York, Oxford University Press.

Hanushek, E. A. (1994). Making Schools Work: Improving Performance and Controlling Costs. Washington, D.C., Brookings.

Hanushek, E. A. and S. G. Rivkin (2006). School quality and the black-white achievement gap. National Bureau of Economic Research Working Paper No. 12651. Cambridge.

Hess, F. M., Ed. (2005). Urban school reform: lessons from San Diego. Cambridge, Harvard Education Press.

Jacob, B. A. and S. D. Levitt (2003). "Rotten Apples: An Investigation of The Prevalence and Predictors of Teacher Cheating." Quarterly Journal of Economics 118(3): 843-877. 
Johnson, S. M., M. L. Donaldson, et al. (2007). Leading the Local: Teachers Union Presidents Speak on Change, Challenges. Education Sector Reports. Washington, D.C., Education Sector.

Kemple, J. J. (2004). Career Academies: Impacts on Labor Market Outcomes and Educational Attainment New York, MDRC.

Lavy, V. (2007). "Using Performance-Based Pay to Improve the Quality of Teachers." The Future of Children 17(1): 87-109.

Levy, F. and R. J. Murnane (2004). The New Division of Labor: How Computers are Creating the Next Labor Market. Princeton, N.J., Princeton University Press. Loewenstein, G. (1999). "Because it is there: the challenge of mountaineering --- for utililty theory " Kyklos 52(3): 315-344.

Murnane, R. J. (forthcoming 2007). "Improving the Education of Children Living in Poverty." The Future of Children.

Murnane, R. J. and D. K. Cohen (1986). "Merit Pay and the Evaluation Problem: Why Most Merit Pay Plans Fail and a Few Survive." Harvard Educational Review 56(1): 1-17.

Murnane, R. J. and F. Levy (1996). Teaching the New Basic Skills. New York, Free Press.

Project, T. A. D. (2004). Ready or Not: Creating a High School Diploma that Counts. Washington D.C., Achieve.

Quint, J. (2006). Meeting Five Critical Challenges of High School Reform. New York, MDRC.

Reville, P., Ed. (2007). A Decade of Urban School Reform: Persistence and Progress in the Boston Public Schools Cambridge, Harvard Education Press. 
Rice, J. M. (1969). The Public-School System of the United States. New York, Arno Press.

Riis, J. A. (1892). The Children of the Poor. New York, Scribner's Sons.

Sharkey, N. S. and R. J. Murnane (2006). "Tough choices in Designing a formative assessment system." American Journal of Education 112(4): 572-588.

Sizer, T. R. (1968). The Schools in the City. The Metropolitan Enigma. J. Q. Wilson. Cambridge, Harvard University Press: 311-349.

${ }^{1}$ Riis, J. A. (1892). The Children of the Poor. New York, Scribner's Sons., and Rice, J. M. (1969). The Public-School System of the United States. New York, Arno Press.

${ }^{2}$ Coleman, J. S. and a. others (1966). Equality of Educational Opportunity. Washington, D.C., Office of Education, U.S. Department of Health, Education, and Welfare.

${ }^{3}$ Sizer, T. R. (1968). The Schools in the City. The Metropolitan Enigma. J. Q. Wilson. Cambridge, Harvard University Press: 311-349.

${ }^{4}$ Hanushek, E. A. and S. G. Rivkin (2006). School quality and the black-white achievement gap. National Bureau of Economic Research Working Paper No. 12651. Cambridge.

${ }^{5}$ Becker, H. S. (1952). "The Career of the Chicago Public SchoolTeacher." American Journal of Sociology 57(5): 470-77.

${ }^{6}$ Graham, P. A. (2006). Schooling America: How the Public Schools Meet the Nation's Changing Needs New York, Oxford University Press.

${ }^{7}$ Murnane, R. J. and F. Levy (1996). Teaching the New Basic Skills. New York, Free Press.

${ }^{8}$ Figure 1 is taken from Levy, F. and R. J. Murnane (2004). The New Division of Labor: How Computers are Creating the Next Labor Market. Princeton, N.J., Princeton University Press..

${ }^{9}$ Figure 2 is based on data taken from the U.S. Current Population Survey.

${ }^{10}$ Figure 3 is a revised version of a figure that originally appeared in Autor, D. H., F. Levy, et al. (2003a). "The Skill Content of Recent Technological Change: An Empirical Exploration." Quarterly Journal of Economics 118(4): 1279-1333.

${ }^{11}$ Figure 4 is constructed from data taken from the U.S. Current Population Survey, as reported on the Economic Policy website: http://www.epi.org/content.cfm/datazone_dznational.

${ }^{12}$ Data are from U.S. Current Population Survey and were taken from the Economic Policy Institute Data Zone, www.epinet.org/datazone/05/wagebyed_a.xls. 
${ }^{13}$ U.S. Department of Education, National Center for Education Statistics (2005). The Condition of Education 2005 (NCES 2005-094. Washington, DC: US Government Printing Office. Table 14.2, page 142.

14 See Evans, W. N., S. E. Murray, et al. (1999). The Impact of Court-Mandated School Finance Reform Equity and Adequacy in Education Finance: Collected Papers H. F. Ladd. Washington, D.C., National Academy Press.

${ }^{15}$ This description of standards-based educational reforms is taken from Levy, F. and R. J. Murnane (2004). The New Division of Labor: How Computers are Creating the Next Labor Market. Princeton, N.J., Princeton University Press., pp. 134-135.

${ }^{16}$ For a discussion of the strengths and weaknesses of NCLB, see Murnane, R. J. (forthcoming 2007). "Improving the Education of Children Living in Poverty." The Future of Children.

${ }^{17}$ Corcoran, S. P., W. N. Evans, et al. (2004). "Women, the Labor Market, and the Declining Relative Quality of Teachers." Journal of Policy Analysis and Management 23(3): 449-470.

${ }^{18}$ For a discussion of this line of reasoning, see Freeman, R. B. (1985). What Do Unions Do. New York, Basic Books.

${ }^{19}$ Johnson, S. M., M. L. Donaldson, et al. (2007). Leading the Local: Teachers Union Presidents Speak on Change, Challenges. Education Sector Reports. Washington, D.C., Education Sector., p 15.

${ }^{20}$ For a discussion of the elements of urban school district reform, see Reville, P., Ed. (2007). A Decade of Urban School Reform: Persistence and Progress in the Boston Public Schools Cambridge, Harvard Education Press.

${ }^{21}$ See Elmore, R. F. (2002). Bridging the gap between standards and achievement: The imperative for professional development in education. Washington, DC, Albert Shanker Institute: 40.

${ }^{22}$ Sharkey, N. S. and R. J. Murnane (2006). "Tough choices in Designing a formative assessment system." American Journal of Education 112(4): 572-588.

${ }^{23}$ This description of the evidence about how to teach English-language-learners effectively is taken from Francis, D. J., N. K. Lesaux, et al. (2006). Language of instruction for language minority learners. Developing Literacy in a second language: Report of the National Literacy Panel. D. L. August and T. Shanahan. Mahwah, N.J., Erlbaum Associates: 365-414.

${ }^{24}$ Quint, J. (2006). Meeting Five Critical Challenges of High School Reform. New York, MDRC.

${ }^{25}$ See Hess, F. M., Ed. (2005). Urban school reform: lessons from San Diego. Cambridge, Harvard Education Press.

${ }^{26}$ See Ibid. and Reville, P., Ed. (2007). A Decade of Urban School Reform: Persistence and Progress in the Boston Public Schools Cambridge, Harvard Education Press.

${ }^{27}$ Hanushek, E. A. (1994). Making Schools Work: Improving Performance and Controlling Costs. Washington, D.C., Brookings.

${ }^{28}$ Clotfelter, C., E. Glennie, et al. (2006). "Would Higher Salaries Keep Teachers in High-Poverty Schools? Evidence from a Policy Intervention in North Carolina." National Bureau of Economic Research Working Paper No. 12285.

${ }^{29}$ Cantrell, S., J. Fullerton, et al. (2007). National Board Certification and Teacher Effectiveness: Evidence from a Random Assignment Experiment. National Bureau of Economic Research Economics of Education Workshop. Cambridge. 
30 Lavy, V. (2007). "Using Performance-Based Pay to Improve the Quality of Teachers." The Future of Children 17(1): 87-109.

31 Ibid.

${ }^{32}$ Bishop, J. H., F. Mane, et al. (2001). The Role of End-of-Course Exams and Minimal Competency Exams in Standards-Based Reforms. Brookings Papers in Education Policy 2001. D. Ravitch. Washington, D.C., Brookings.

33 Project, T. A. D. (2004). Ready or Not: Creating a High School Diploma that Counts. Washington D.C., Achieve., executive summary, p. 2.

34 The text in this section borrows heavily from Murnane, R. J. (forthcoming 2007). "Improving the Education of Children Living in Poverty." The Future of Children.

${ }^{35}$ For a discussion of the reason these skills are increasingly important in workplaces full of computers, see Levy, F. and R. J. Murnane (2004). The New Division of Labor: How Computers are Creating the Next Labor Market. Princeton, N.J., Princeton University Press.

${ }^{36}$ Kemple, J. J. (2004). Career Academies: Impacts on Labor Market Outcomes and Educational Attainment New York, MDRC.

${ }^{37}$ Murnane, R. J. and D. K. Cohen (1986). "Merit Pay and the Evaluation Problem: Why Most Merit Pay Plans Fail and a Few Survive." Harvard Educational Review 56(1): 1-17. 38 Jacob, B. A. and S. D. Levitt (2003). "Rotten Apples: An Investigation of The Prevalence and Predictors of Teacher Cheating." Quarterly Journal of Economics 118(3): 843-877.

39 Figlio, D. N. (2005). "Testing, Crime and Punishment." National Bureau of Economic Research Working Paper No. 11194.

${ }^{40}$ Loewenstein, G. (1999). "Because it is there: the challenge of mountaineering --- for utililty theory " Kyklos 52(3): 315-344.

${ }^{41}$ Information copied from the following website on April 17, 2007:

http://www.nslc.org/outreach/default.htm. The website reports that the National Student Clearinghouse currently provides information for students attending more than 2900 institutions. Currently 91 percent of the nation's college and university students are enrolled in these institutions. 